\title{
Clinical pearls: Laboratory assessments of direct oral anticoagulants (DOACS)
}

\section{Robert C. Gosselin'; Jonathan Douxfils²; Dorothy Adcock ${ }^{3}$}

${ }^{1}$ University of California, Davis Health System, Pathology and Laboratory Medicine, Sacramento, California, United States; ${ }^{2}$ Université de Namur, Pharmacy, Namur, Belgium; ${ }^{3}$ Laboratory Corporation of America ${ }^{\circledR}$ Holdings - Colorado Coagulation, Englewood, Colorado, United States

Keywords

Dabigatran, rivaroxaban, apixaban, edoxaban, direct oral anticoagulants

\section{Summary}

Direct oral anticoagulants (DOACS) are being used for stroke prevention in patients with atrial fibrillation as well as for prophylaxis and treatment of venous thromboembolism. Clinicians who treat, or may encounter, patients with DOAC exposure, should be aware of the limitations of coagulation testing in this setting, and seek counsel from their laboratory to understand the effects of DOACS on coagulation results. Generally, assays that employ clot based principles, or methods that require thrombin or Factor $\mathrm{Xa}$ activation or substrates may be affected by the presence of DOACS. The clinical laboratory should have an algorithmic testing plan for adequately assessing the presence of all DOACS and readily provide this information to clinicians. We describe Clinical Pearls for DOAC assessment using common and esoteric coagulation testing.

\section{Schlüsselwörter}

Dabigatran, Rivaroxaban, Apixaban, Edoxaban, direkte orale Antikoagulanzien

\section{Zusammenfassung}

Direkte orale Antikoagulanzien (DOAK) werden zur Schlaganfallprophylaxe bei Patienten mit Vorhofflimmern und zur Prophylaxe sowie Behandlung von venösen Thrombembolien eingesetzt. Ärzte, die Patienten unter DOAK-Therapie behandeln oder mit diesen konfrontiert werden, sollten sich über die Grenzen der Bestimmung der Gerinnungswerte unter diesen Bedingungen im Klaren sein. Sie sollten den Rat ihres Labors einholen, um die Wirkungen der DOAK auf die Gerinnungswerte richtig einzuschätzen. Generell können Assays, die auf funktionellen Clotting-Tests basieren, oder Methoden, die Thrombin oder Faktor Xa als Substrat verwenden bzw. deren Aktivierung erfordern, von DOAK beeinflusst werden. Das klinische Labor sollte über einen algorithmischen Testplan verfügen, um die Präsenz aller DOAK in geeigneter Weise zu beurteilen und den Ärzten diese Informationen umgehend zur Verfügung stellen zu können. Wir beschreiben klinische Perlen für die DOAK-Untersuchung anhand der üblichen Gerinnungstests wie auch selteneren Verfahren.

Laborbeurteilung von direkten oralen Antikoagulanzien (DOAKs)

Hämostaseologie 2017; 37: 295-301 https://doi.org/10.5482/HAM0-17-01-0002 received: January 12, 2017 accepted in revised form: May 5, 2017 epub ahead of print: July 5, 2017
Thromboembolic risk is increased in patients with atrial fibrillation, those undergoing orthopedic procedures, trauma, cancer, and other causes. Without adequate pharmaceutical prophylaxis, these patients may have arterial or venous thromboembolic events, including stroke, deep vein thrombosis and pulmonary embolism $(1,2)$. While the administration of heparin for short-term, and vitamin $\mathrm{K}$ antagonists for long term anticoagulation in these patients have not been entirely been supplanted, newer agents have been in use for nearly two decades, specifically low molecular weight heparin for short term anticoagulation, and the direct oral anticoagulants (DOACS) for long term anticoagulation (3).

One common theme with these DOACS is their predictable pharmacokinetics and pharmacodynamics (in most patient populations) and the promise of little to no routine laboratory monitoring (4-7). However, it is mandatory that the clinical laboratory has the capacity to either detect or quantify these anticoagulants or has access to a reference laboratory that can do so (8). In certain populations with known DOAC exposure (e.g. bleeding patients, emergent surgery, trauma, etc) the capacity to measure DOAC concentration in blood may assist the clinician in managing these patients (9). Additionally, in those facilities that may provide emergent services, patients with unclear medication history, or inability to provide a medication history (e.g trauma, stroke, etc), the capacity to screen for recent DOAC exposure may also guide management (e.g. lytic therapy in stroke patient, antidote administration). The notion of "routine" monitoring of patients on DOACS remains controversial and is outside the scope of this manuscript. We aim 
to summarize the laboratory methods that can either detect the presence of, or quantify, DOACS in an effort to aide clinicians.

\section{The DOACS}

Direct oral anticoagulants are small molecules that selectively inhibit the active sites of activated factor X (direct FXa inhibitors) or thrombin (direct thrombin inhibitors), both of which are critical enzymes in the common pathway of coagulation ( Tab. 1). Dabigatran is a direct thrombin inhibitor while rivaroxaban, apixaban and edoxaban inhibit activated factor X. Other new direct oral anticoagulants anti-IIa (AZD0837) and anti-Xa (betrixaban, letaxaban, darexaban, eribaxaban) are under pre-clinical or dosefinding investigation (9).

DOACS are used predominantly for thromboprophylaxis in atrial fibrillation and treatment of venous thromboembolism. DOACS are administered at fixed doses. They have a wider therapeutic window than vitamin $\mathrm{K}$ antagonists and a better bleeding profile (10).

Unlike heparins which are indirect inhibitors, DOACS inhibit both free and bound activated factors.

As a class, DOACS have rapid onset (2-4 hours) and are short acting with a plasma elimination half-life of about 12 hours in those with normal renal function. Due to their predictable pharmacodynamics and kinetic properties routine measurement for titration of dose is not required. Pharmacokinetics tends not to be influenced by age, gender, and body weight even if dose reduction is proposed for edoxaban in patients with low body weight $(\leq 60 \mathrm{~kg})$. They vary in their bioavailability, liver metabolism and renal excretion rate although all DOACS have some element of renal excretion $(4,11)$. They are all acted on by the hepatic and gastrointestinal transport protein, P-glycoprotein (P-gp) $(4,12)$. P-gp serves as a mechanism for intestinal excretion. Hepatic clearance is mediated through cytochrome (CYP) 3A4, CYP 2J2 as well as non-cytochrome dependent mechanisms, except for dabigatran which is not metabolized by CYP-dependent reactions. The administration of drugs that inhibit both P-gp and CYP 3A4 (such as ketoconazole of HIV protease inhibitors) can lead to drug accumulation.

DOACS do not demonstrate interaction with food, although it is recommended that rivaroxaban should be taken during meals.

Dabigatran is administered as dabigatran etexilate which is a prodrug converted to dabigatran via hydrolysis by esterase. It is generally administered twice daily at 110 or $150 \mathrm{mg}$ depending on renal function as $80 \%$ is renally excreted $(4,13)$. Rivaroxaban is administered once daily and elimination occurs through renal and non-renal routes. Apixaban is administered twice daily and edoxaban once per day. Apixaban and edoxaban have multiple elimination mechan-

Tab. 1 Pharmacodynamic and pharmacokinetic properties of DOACS (9-14).

\begin{tabular}{l|l|l|l|l}
\hline & Dabigatran & Rivaroxaban & Apixaban & Edoxaban \\
\hline target & thrombin & FXa & FXa & FXa \\
\hline prodrug & yes & no & no & no \\
\hline active metabolite & no & no & no & yes \\
\hline antidote & $\begin{array}{l}\text { FDA and EMA } \\
\text { approved }\end{array}$ & $\begin{array}{l}\text { not FDA ap- } \\
\text { proved }\end{array}$ & $\begin{array}{l}\text { not FDA ap- } \\
\text { proved }\end{array}$ & $\begin{array}{l}\text { not FDA ap- } \\
\text { proved }\end{array}$ \\
\hline administration & once or twice daily & once daily & twice daily & once daily \\
\hline renal excretion & $80 \%$ & $30-40 \%$ & $20-30 \%$ & $30-40 \%$ \\
\hline half-life & $14-17 \mathrm{~h}$ & $7-11 \mathrm{~h}$ & $10-14 \mathrm{~h}$ & $9-11 \mathrm{~h}$ \\
\hline
\end{tabular}

FXa: activated form of coagulation factor X; FDA: Food and Drug Administration; EMA: European Medicines Agency

isms. Given the short half-life of DOACS, compliance with therapy is essential.

\section{Laboratory testing and DOAC anticoagulation}

Early communications from highly regarded laboratory or hemostasis organizations and journals included a number of generic statements relating routine screening tests, the prothrombin time (PT) and activated partial thromboplastin time (aPTT) with DOAC presence, sensitivity, or concentration (13-15). Specifically, these statements included the following general information: The PT is more sensitive to anti-Xa DOACS than the aPTT, and conversely dabigatran tends to affect the aPTT more so than the PT, and that the sensitivity to DOAC concentration depends on the reagent used in the assay $(13,15)$.

While this general information appropriately alluded to limitations and exceptions of the PT and aPTT, these limitations seem to be lost in translation to guidelines from other organizations. Publications from neurosurgical, surgical, anesthesia, critical care related to DOACS and screening coagulation tests tend to suggest the role of the PT and aPTT with and without caveats related to differences noted in reagent sensitivity between manufacturers (16-19). Based on our own institutional experiences, there is low likelihood that clinicians who practice outside the laboratory (e.g. surgeons, emergency department physicians, etc...) are familiar with the specific reagents used in the clinical laboratory, or reference laboratory that provide service to their patients. As such, a general promulgation of misleading information about the utility of these screening tests abounds.

It must be emphasized, that the PT and aPTT are tests that may be useful for screening purposes including assessing patients for factor deficiency, treatment efficacy (e.g. warfarin and other coumarin agents), treatment reversal (e.g. vitamin $\mathrm{K}$, (a)PCC or FFP), and presence of inhibitors. However, other tests such as the dilute thrombin time (dTT) (20), ecarin based methods $(21,22)$ (either ecarin clotting time (ECT) or the chromogenic variant (ECA)), and adapted anti-Xa assay 
(23-25), are more specific to drug monitoring and assessment.

When calibrated with the appropriate DOAC, these methods have demonstrated acceptable or equivalent measurements when compared to accepted means for assessing drug concentration (e.g. mass spectrometry).

Drug calibrated dilute Russell's Viper venom time has demonstrated a linear response to DOAC concentration, both direct thrombin and FXa inhibitors, but conflicting lower level of quantitation data requires further investigation (26-28). Importantly, commercial calibrators and controls should be used specifically with the test for which they are designed and they cannot be used to calibrate or assess the sensitivity of global assays such as the PT and the aPTT. However, the combination of the screening and drug quantitation laboratory assays would optimize the assessment of a patient with known and unknown medication history (8).

Other methods for assessing DOAC anticoagulation include thromboelastometry (TEG or ROTEM), and urinary measurements of excreted metabolites (29-31). Both offer some potential utility in emergent situations. However, other causes for prolonged R time (TEG) or CT time (ROTEM) and the lack of correlation of urinary DOAC results with blood concentrations are potential limiting factors.

Thus, quantifying DOAC exposure is technically possible but there are currently no established, "therapeutic" ranges. However, "on-therapy" ranges are available from the large phase-2/3 studies and can be taken into account in daily practice $(32,33)$.

In addition, experts in the field have proposed specific plasma drug concentration cut-offs to reduce the risk of hemorrhagic complications in the perioperative setting while others have proposed thresholds to guide the administration of reversal agents and these uses would require laboratory measurement $(19,34)$.

\section{Clinical pearls with PT and DOACS}

- Most PT reagents demonstrate a linear, drug dependent concentration effect with most DOACS $(8,35-40)$.

- All PT reagents demonstrate variable degree of sensitivity to DOACS (8, 35-40).

- PT is practically insensitive to apixaban $(8,41-43)$.

- Within a single manufacturer, PT reagents are generally more sensitive to anti-Xa DOACS than dabigatran, except for apixaban $(5,44)$.

- Use of commercial calibrators or controls to assess local sensitivity to DOAC may not be optimal for all reagent systems as commercial calibrators or controls may not have the appropriate matrix for a plasma-based assays $(8,45)$.

- Use of drug enriched normal plasma (i.e. plasma from healthy donor in which the drug is added in vitro) to assess reagent sensitivity to DOAC may not reflect the same reagent sensitivity as seen in patient samples $(8$.

- Correlation between in vivo DOACS plasma concentrations and PT prolongation depends on the reagent and is generally poor (38).

\section{Clinical pearls with aPTT and DOACS}

- Most aPTT reagents demonstrate a curvi-linear, drug dependent concentration effect with DOACS meaning the aPTT in seconds tends to plateau with increasing drug concentration $(8,25$, 35-37, 39, 40).

- All aPTT reagents demonstrate variable degree of sensitivity to DOACS $(8,25$, 35-37, 39, 40).

- Within a single manufacturer, aPTT reagents are generally more sensitive to dabigatran than anti-Xa DOACS (5).

- Use of commercial calibrators or controls to assess local sensitivity to DOAC may not be optimal for all reagent systems $(8,45)$.

- Use of drug enriched normal plasma to assess reagent sensitivity to DOAC may not reflect the same reagent sensitivity as seen in patient samples (8).

- Correlation between DOACS plasma concentrations in patients and aPTT prolongation in seconds depends on the reagent and is generally poor (46).

\section{Clinical pearls: known or unknown DOAC exposure}

PT or aPTT may not be sufficiently sensitive to rule out significant levels of drug (>30 ng/mL) $(5,44)$.

- Dabigatran affects the aPTT (for most reagents) more so than PT (for most reagents) $(36,37)$.

- $\mathrm{STA}^{\star}$ Neoplastine CI Plus is sensitive to rivaroxaban, but not apixaban (39-43).

- Dade Innovin ${ }^{\circledast}$ is insensitive to all antiXa DOACS $(39,40,43)$.

- Apixaban impacts the PT at a given drug concentration to a lesser degree than rivaroxaban or edoxaban (42).

- In vitro studies may not reflect same degree of reagent sensitivity as samples from patients on DOAC therapy (8).

- Use of commercial calibrators and controls to locally assess DOAC sensitivity may be misleading to reagent sensitivity as compared to real patient samples $(8,45)$.

A prolonged PT and/or aPTT in a patient with known DOAC exposure should be considered to be secondary to the drug, until proven otherwise.

- Studies suggest mixing studies, factor assays in samples containing DOAC may gave factitious results $(39,47,48)$.

- Antibiotic use may impact intestinal flora which may result in acute vitamin $\mathrm{K}$ factor deficiency, thereby affecting PT (and aPTT) (49).

- Lipoglycopeptide antibiotics may affect the PT and aPTT due to interference with phospholipids within PT/aPTT reagents (50).

- Lupus anticoagulants may result in prolonged aPTT (and with less frequency, the PT) (51).

- Compromised liver function or consumption coagulopathy may also result in prolonged $\mathrm{PT}$ and/or $\mathrm{aPTT}$. 
Tab. 2 Effect of dabigatran on coagulation assays $(5,8,13,14,20,22,26,27,32,37,41,43,45-47,52,53)$.

\begin{tabular}{|c|c|c|c|c|}
\hline effect & clot based assays & chromogenic based assays & $\begin{array}{l}\text { immunoAssays } \\
\text { (e.g. LIA, ELISA) }\end{array}$ & $\begin{array}{l}\text { clinical impact of } \\
\text { reported test result }\end{array}$ \\
\hline $\begin{array}{l}\text { linear relationship between } \\
\text { prolonged clotting time and } \\
\text { increased reported result }\end{array}$ & $\begin{array}{l}\text { - } \mathrm{PT} / \mathrm{INR}^{1,2} \\
\text { - } \text { aPTT }^{1,2} \\
\text { - thrombin time } \\
\text { - ecarin based assays }\end{array}$ & & none & $\begin{array}{l}\text { - diagnosis and/or } \\
\text { management }\end{array}$ \\
\hline $\begin{array}{l}\text { relationship between } \\
\text { dabigatran presence and } \\
\text { factitiously decreased } \\
\text { reported result }\end{array}$ & $\begin{array}{l}\text { fibrinogen }{ }^{2,3} \\
\text { factor activity } \\
\text { (II, V, VII, VIII, IX, X, XI, XII) }\end{array}$ & & none & $\begin{array}{l}\text { - (mis)diagnosis and/or } \\
\text { (mis)management }\end{array}$ \\
\hline $\begin{array}{l}\text { relationship between } \\
\text { dabigatran presence and } \\
\text { factitiously increased } \\
\text { reported result }\end{array}$ & $\begin{array}{l}\text { - inhibitor screen }{ }^{1,2} \\
\text { inhibitor assay }{ }^{1,2} \\
\text { - lupus anticoagulant }{ }^{1} \\
\text { - protein C activity }{ }^{1,2} \\
\text { protein } \text { activity }^{1,2} \\
\text { APCR }{ }^{1,2}\end{array}$ & $\begin{array}{l}\text { antithrombin }{ }^{2} \\
\text { (thrombin substrate) }\end{array}$ & none & $\begin{array}{l}\text { - (mis)diagnosis and/or } \\
\text { (mis)management }\end{array}$ \\
\hline no effect & - reptilase time & $\begin{array}{l}\text { - antithrombin } \\
\text { (factor Xa substrate) } \\
\text { - protein C activity } \\
\text { - plasminogen activity } \\
\text { - alpha-2-antiplasmin } \\
\text { - factor XIII activity } \\
\text { - factor VIII Activity }\end{array}$ & $\begin{array}{l}\text { - protein C antigen } \\
\text { total/free protein S } \\
\text { antigen } \\
\text { VWF activity and } \\
\text { antigen }\end{array}$ & $\begin{array}{l}\text { none - desired testing, } \\
\text { when clinically necessary } \\
\text { or relevant }\end{array}$ \\
\hline
\end{tabular}

${ }^{1}$ reagent dependent

${ }^{2}$ concentration dependent

${ }^{3}$ For fibrinogen - if measured using the Clauss method, most reagents will not be affected. For PT-derived measurements, results are more likely to be factitiously increased.

A prolonged PT and/or aPTT in a patient with unknown DOAC exposure would require further assessment, including, but not limited to:

\section{- Mixing studies}

- Presence of inhibitor or factor deficiency

- Thrombin time (TT)

- Markedly prolonged TT would suggest dabigatran presence especially if the TT does not normalize with heparinase and if the reptilase time is normal, but cannot completely exclude rare causes (e.g. dys-, hypo-, afribrinogenemia, inflammatory responses, to name a few) (52).

- Chromogenic anti-Xa test

- Positive "signal" would suggest presence of anti-Xa class of drugs, including heparins or DOACS $(41,43,46,53,54)$.

- Cannot readily differentiate anti-Xa class of drugs, including heparins or DOACS, except for some tests, specifically designed to be insensitive to heparins (e.g. the Biophen Direct FXa inhibitors ${ }^{\circledast}$ assay).
Consultation with appropriate laboratory personnel to interpret the test results in a patient with unknown or unclear medication history should be considered (8).

\section{Clinical pearls: quantifying DOAC concentration}

In order to properly interpret the results of such quantitative assays, it is essential to know the clinical situation for which the quantitative measurement is requested. Specific cut-offs have been established in perioperative setting to support the administration of reversal agents in high-risk procedures (i.e. $30 \mathrm{ng} / \mathrm{mL}$ ) or in bleeding patients (i.e. $50 \mathrm{ng} / \mathrm{mL})(19,34)$. In any cases, it is mandatory to know the delay since the last dose was taken in order to know if the plasma concentration is increasing or not. In a random sample, comparison of the patient's plasma level with the results of ontherapy ranges observed in large phase-3 trials may be helpful (32).
If quantifying DOACS is required: Rapid methods calibrated using commercial or locally prepared DOAC plasma of known concentrations.

- Dabigatran - only commercially prepared calibration material would be acceptable as dabigatran is administered as a prodrug (dabigatran etexilate) that is converted into the active drug, dabigatran in vivo.

- Anti-FXa DOACS - commercially prepared or locally prepared calibration material using drug dissolved in Dimethyl sulfoxide (DMSO).

Rapid tests can be easily adapted and performed on most automated coagulation analyzers, and for clot based assays using manual methods (e.g. tilt tube, fibrometer) as well:

- For dabigatran, drug calibrated assays to quantitate plasma drug concentration:

- Dilute thrombin time $(20,37)$

- Ecarin clotting time $(21,37)$

- Ecarin chromogenic assay $(22,37)$ 
Tab. 3 Effect of anti-Xa DOACS on coagulation assays $(5,8,13-15,24-26,28,30,32,35,38-42,45,48,53,56,58)$.

\begin{tabular}{|c|c|c|c|c|}
\hline effect & clot based assays & $\begin{array}{l}\text { chromogenic based } \\
\text { assays }\end{array}$ & $\begin{array}{l}\text { immunoAssays } \\
\text { (e.g. LIA, ELISA) }\end{array}$ & $\begin{array}{l}\text { clinical impact of } \\
\text { reported test result }\end{array}$ \\
\hline $\begin{array}{l}\text { relationship between } \\
\text { prolonged clotting time } \\
\text { and increased reported } \\
\text { result }\end{array}$ & $\begin{array}{l}\mathrm{PT} / \mathrm{INR}^{1,2,3} \\
\mathrm{aPTT} \\
1,2,3\end{array}$ & & none & $\begin{array}{l}\text { diagnosis and/or } \\
\text { management }\end{array}$ \\
\hline $\begin{array}{l}\text { relationship between } \\
\text { DOAC presence and } \\
\text { factitiously decreased } \\
\text { reported result }\end{array}$ & $\begin{array}{l}\text { factor activity }{ }^{1,2,3} \\
\text { (II, V, VII, VIII, IX, X, XI, XII) }\end{array}$ & $\begin{array}{l}\text { - factor VIII } \\
\text { - factor IX }\end{array}$ & none & $\begin{array}{l}\text { (mis)diagnosis and/or } \\
\text { (mis)management }\end{array}$ \\
\hline $\begin{array}{l}\text { relationship between } \\
\text { DOAC presence and } \\
\text { factitiously increased } \\
\text { reported result }\end{array}$ & $\begin{array}{l}\text { inhibitor screen }{ }^{1,2,3} \\
\text { inhibitor assay } 1,2,3 \\
\text { - lupus anticoagulant }{ }^{1,2} \\
\text { protein C activity }{ }^{1,2} \\
\text { protein } \text { activity }^{1,2} \\
\text { - } \text { APCR }{ }^{1,2}\end{array}$ & $\begin{array}{l}\text { antithrombin }{ }^{2} \\
\text { (factor Xa substrate) } \\
\text { unfractionated heparin, } \\
\text { low molecular weight } \\
\text { heparin, or } \\
\text { - heparinoids/penta- } \\
\text { saccharide }\end{array}$ & none & $\begin{array}{l}\text { (mis)diagnosis and/or } \\
\text { (mis)management }\end{array}$ \\
\hline no effect & $\begin{array}{l}\text { fibrinogen } \\
\text { - thrombin time } \\
\text { - reptilase time } \\
\text { - ecarin based assays }\end{array}$ & $\begin{array}{l}\text { antithrombin } \\
\text { (thrombin substrate) } \\
\text { protein C activity } \\
\text { plasminogen activity } \\
\text { alpha-2-antiplasmin } \\
\text { factor XIII activity }\end{array}$ & $\begin{array}{l}\text { protein C antigen } \\
\text { total/free protein S } \\
\text { antigen } \\
\text { VWF activity and antigen }\end{array}$ & $\begin{array}{l}\text { none - desired testing, } \\
\text { when clinically necessary or } \\
\text { relevant }\end{array}$ \\
\hline
\end{tabular}

${ }^{1}$ reagent dependent

2 concentration dependent

${ }^{3}$ Apixaban usually not affecting result

- Dilute Russell's Viper venom time $(26,27)$

- Chromogenic anti-IIa method (55)

- For anti-FXa DOACS drug calibrated assays to quantitate plasma drug concentration:

- Chromogenic anti-Xa method (25, 28, 33, 38, 39, 41-43, 56)

- Dilute Russell's Viper venom time $(26,27)$

For non-emergent sample testing, in addition to methods described above, mass spectrometry, or equivalent, methods for quantifying DOACS could be consider, whether performed locally or at reputable reference laboratories (33, 57-59).

\section{Clinical pearls: DOACS may affect a range of laboratory tests and caution must be used when interpreting these data}

- Dabigatran presence may affect other coagulation assays: factitiously low or high results ( Tab. 2).

- Anti-FXa DOACS may affect other coagulation assays: factitiously low or high results ( $>$ Tab. 3 ).

- Test methods based on latex immunoassay (LIA), enzyme-linked immunoassay (ELISA), or chromogenic methods without thrombin or anti-Xa substrates or methodologies are not affected by DOACS presence.

- Coagulation tests affected by DOACS but are not required for assessing the anticoagulant effect of DOACS (e.g. used for diagnostic purposes) should be avoided.
- If diagnostic tests are required while on DOACS, a trough collection may minimize the DOAC effect, but a concomitant DOAC level would be useful in interpreting the test result.

\section{Conclusion: DOAC anticoagulation and the clinical laboratory}

It is essential for any clinician who treats, or may encounter, patients with DOAC exposure consults with the laboratory on any (normal or abnormal) coagulation test result(s) to discuss the merits and limitations of the test in that setting. Additionally, any coagulation assay that employs clot based principles, or methods that have thrombin or anti-Xa activation or substrates should be avoided or the results interpreted with caution. Lastly, it is essential that the clinical laboratory have an algorithmic testing plan for adequately assessing the presence of all DOACS that are approved for clinical 
use, and provide the treating clinician with potential diagnostic strategies, especially in emergent situations, which may be necessary to provide optimal care and patient safety.

\section{Conflict of interest}

RCG provides expert testimony for laboratory monitoring or rivaroxaban and dabigatran; JD reports personal fees from Stago, personal fees from Daiichi-Sankyo, outside the submitted work; DA reports personal fees from Stago and Roche outside the submitted work.

\section{References}

1. Kearon C, Akl EA, Comerota AJ et al. Antithrombotic therapy for VTE disease: Antithrombotic Therapy and Prevention of Thrombosis, 9th ed: American College of Chest Physicians EvidenceBased Clinical Practice Guidelines. Chest 2012; 141: e419S-94S

2. You JJ, Singer DE, Howard PA et al. Antithrombotic therapy for atrial fibrillation: Antithrombotic Therapy and Prevention of Thrombosis, 9th ed: American College of Chest Physicians EvidenceBased Clinical Practice Guidelines. Chest 2012; 141: e531S-75S

3. Barnes GD, Ageno W, Ansell J et al. Recommendation on the Nomenclature for Oral Anticoagulants: communication from the SSC of the ISTH. J Thromb Haemost 2015; 13(6): 1154-1156.

4. Nutescu EA, Burnett A, Fanikos Jet al. Pharmacology of anticoagulants used in the treatment of venous thromboembolism. J Thromb Thrombolys 2016; 41: 15-31.

5. Cuker A, Siegal DM, Crowther MA, Garcia DA. Laboratory measurement of the anticoagulant activity of the non-vitamin $\mathrm{K}$ oral anticoagulants. J Am Coll Cardiol 2014; 64: 1128-1139.

6. Giugliano RP, Ruff CT, Braunwald E et al. Edoxaban versus warfarin in patients with atrial fibrillation. N Engl J Med 2013; 369: 2093-2104.

7. Ageno W, Gallus AS, Wittkowsky A et al. Antithrombotic Therapy and Prevention of Thrombosis, 9th ed: American College of Chest Physicians Evidence-Based Clinical Practice Guidelines. Chest 2012; 141: e44S-88S.

8. Gosselin RC, Adcock DM. The laboratory's 2015 perspective on direct oral anticoagulant testing. J Thromb Haemost 2016; 14: 886-893.

9. Masotti L, Campanini M. Pharmacology of new oral anticoagulants: mechanism of action, pharmacokinetics, pharmacodynamics. Ital J Med 2013; 7: 1 .

10. Bauer KA. Targeted Anti-Anticoagulants. N Engl J Med 2015; 373: 569-571.

11. Ieko M, Naitoh S, Yoshida M, Takahashi N. Profiles of direct oral anticoagulants and clinical usage-dosage and dose regimen differences. J Intens Care 2016; 4: 19.
12. Salem JE, Sabouret P, Funck-Brentano C, Hulot JS. Pharmacology and mechanisms of action of new oral anticoagulants. Fundam Clin Pharmacol 2015; 29: 10-20.

13. Baglin T, Hillarp A, Tripodi A et al. Measuring Oral Direct Inhibitors (ODIs) of thrombin and factor Xa: A recommendation from the Subcommittee on Control of Anticoagulation of the Scientific and Standardisation Committee of the International Society on Thrombosis and Haemostasis. J Thromb Haemost 2013; 11: 756-760.

14. Baglin T, Keeling D, Kitchen S, British Committee for Standards in H. Effects on routine coagulation screens and assessment of anticoagulant intensity in patients taking oral dabigatran or rivaroxaban: guidance from the British Committee for Standards in Haematology. Brit J Haematol 2012; 159: 427-429.

15. Harenberg J, Du S, Weiss C et al. Methods to determine apixaban of the Subcommittee on Control of Anticoagulation of the International Society of $\mathrm{T}$ and Haemostasis. Report of the Subcommittee on Control of Anticoagulation on the determination of the anticoagulant effects of apixaban: communication from the SSC of the ISTH. J Thromb Haemost 2014; 12: 801-804.

16. Tran H, Joseph J, Young L et al. New oral anticoagulants: a practical guide on prescription, laboratory testing and peri-procedural/bleeding management. Australasian Society of Thrombosis and Haemostasis. Intern Med J 2014; 44: 525-536.

17. Benzon HT, Avram MJ, Green D and Bonow RO. New oral anticoagulants and regional anaesthesia. Brit J Anaest 2013; 111 (Suppl 1): i96-113.

18. Koscielny J, Rutkauskaite E. Rivaroxaban and hemostasis in emergency care. Emerg Med Internat 2014; 2014: 935474.

19. Pernod G, Albaladejo P, Godier A et al. Management of major bleeding complications and emergency surgery in patients on long-term treatment with direct oral anticoagulants, thrombin or factor-Xa inhibitors: proposals of the working group on perioperative haemostasis (GIHP) - March 2013. Arch Cardiovasc Dis 2013; 106: 382-393.

20. Hapgood G, Butler J, Malan E et al. The effect of dabigatran on the activated partial thromboplastin time and thrombin time as determined by the Hemoclot thrombin inhibitor assay in patient plasma samples. Thromb Haemost 2013; 110: 308-315.

21. Nowak G. The ecarin clotting time, a universal method to quantify direct thrombin inhibitors. $\mathrm{Pa}$ thophysiol Haemost Thromb 2003; 33: 173-183.

22. Gosselin RC, Dwyre DM, Dager WE. Measuring dabigatran concentrations using a chromogenic ecarin clotting time assay. Ann Pharmacother 2013; 47: 1635-1640.

23. Harenberg J, Erdle S, Marx S, Kramer R. Determination of rivaroxaban in human plasma samples. Sem Thromb Hemost 2012; 38: 178-184.

24. Hillarp A, Gustafsson KM, Faxalv L et al. Effects of the oral, direct factor Xa inhibitor apixaban on routine coagulation assays and anti-FXa assays. J Thromb Haemost 2014; 12: 1545-1553.

25. Douxfils J, Chatelain B, Chatelain C et al. Edoxaban: Impact on routine and specific coagulation assays. A practical laboratory guide. Thromb Haemost 2016; 115: 368-381.

26. Douxfils J, Chatelain B, Hjemdahl P et al. Does the Russell Viper Venom time test provide a rapid esti- mation of the intensity of oral anticoagulation? A cohort study. Thrombos Res 2015; 135: 852-860.

27. McGlasson DL, Fritsma GA. Measuring dabigatran with the dilute Russell viper venom confirm assay in an anticoagulation clinic population. Blood Coagul Fibrinolysis 2016; 27: 53-57.

28. Gosselin RC, Adcock Funk DM, Taylor JM et al. Comparison of anti-Xa and dilute Russell viper venom time assays in quantifying drug levels in patients on therapeutic doses of rivaroxaban. Arch Pathol Lab Med 2014; 138: 1680-1684.

29. Dias JD, Norem K, Doorneweerd DD et al. Use of Thromboelastography (TEG) for Detection of New Oral Anticoagulants. Arch Pathol Lab Med 2015; 139: 665-673.

30. Adelmann D, Wiegele M, Wohlgemuth RK et al. Measuring the activity of apixaban and rivaroxaban with rotational thrombelastometry. Thromb Res 2014; 134: 918-923.

31. Harenberg J, Du S, Kramer S et al. Patients' Serum and Urine as Easily Accessible Samples for the Measurement of Non-Vitamin K Antagonist Oral Anticoagulants. Semin Thromb Hemost 2015; 41: 228-3632.

32. Douxfils J, Gosselin RC. Laboratory Assessment of Direct Oral Anticoagulants. Semin Thromb Hemost 2017;43: 277-290.

33. Douxfils J, Pochet L, Lessire S et al. Mass spectrometry in the therapeutic drug monitoring of direct oral anticoagulants. Useful or useless? Trend Anal Chem 2016; 84 (Part B): 41-50.

34. Levy JH, Ageno W, Chan NC et al. When and how to use antidotes for the reversal of direct oral anticoagulants: guidance from the SSC of the ISTH. J Thromb Haemost 2016; 14: 623-627.

35. Francart SJ, Hawes EM, Deal AM et al. Performance of coagulation tests in patients on therapeutic doses of rivaroxaban. A cross-sectional pharmacodynamic study based on peak and trough plasma levels. Thromb Haemost 2014; 111: 1133-1140.

36. Hawes EM, Deal AM, Funk-Adcock D et al. Performance of coagulation tests in patients on therapeutic doses of dabigatran: a cross-sectional pharmacodynamic study based on peak and trough plasma levels. J Thromb Haemost 2013; 11 : 1493-1502.

37. Douxfils J, Mullier F, Robert S et al. Impact of dabigatran on a large panel of routine or specific coagulation assays. Laboratory recommendations for monitoring of dabigatran etexilate. Thromb Haemost 2012; 107: 985-997.

38. Douxfils J, Tamigniau A, Chatelain B et al. Comparison of calibrated chromogenic anti-Xa assay and PT tests with LC-MS/MS for the therapeutic monitoring of patients treated with rivaroxaban. Thromb Haemost 2013; 110: 723-731.

39. Douxfils J, Chatelain C, Chatelain B et al. Impact of apixaban on routine and specific coagulation assays: a practical laboratory guide. Thromb Haemost 2013; 110: 283-294.

40. Dale BJ, Ginsberg JS, Johnston M et al. Comparison of the effects of apixaban and rivaroxaban on prothrombin and activated partial thromboplastin times using various reagents. J Thromb Haemost 2014; 12:1810-1815.

41. Adcock DM, Gosselin R. Direct Oral Anticoagulants (DOACS) in the Laboratory: 2015 Review. Thromb Res 2015; 136: 7-12. 
42. Gosselin R, Grant RP, Adcock DM. Comparison of the effect of the anti-Xa direct oral anticoagulants apixaban, edoxaban, and rivaroxaban on coagulation assays. Int J lab Hematol 2016; 38: 505-513.

43. Gosselin RC, Adcock DM. Assessing nonvitamin $\mathrm{K}$ antagonist oral anticoagulants (NOACs) in the laboratory. Int J lab Hematol 2015; 37 (Suppl 1): 46-51.

44. Lippi G, Favaloro E. Laboratory Testing in the Era of Direct or Non-Vitamin K Antagonist Oral Anticoagulants: A Practical Guide to Measuring Their Activity and Avoiding Diagnostic Errors. Sem Throm Hemost 2015; 41: 208-227.

45. Gosselin RC, Adcock D, Hawes EM et al. Evaluating the use of commercial drug-specific calibrators for determining PT and APTT reagent sensitivity to dabigatran and rivaroxaban. Thromb Haemost 2015; 113: 77-84

46. Douxfils J, Dogne JM, Mullier F et al. Comparison of calibrated dilute thrombin time and aPTT tests with LC-MS/MS for the therapeutic monitoring of patients treated with dabigatran etexilate. Thromb Haemost 2013; 110: 543-549.

47. Adcock DM, Gosselin R, Kitchen S, Dwyre DM. The effect of dabigatran on select specialty coagulation assays. Am J Clin Pathol 2013; 139: 102-109.

48. Bonar R, Favaloro EJ, Mohammed et al. The effect of the direct factor Xa inhibitors apixaban and rivaroxaban on haemostasis tests: a comprehensive assessment using in vitro and ex vivo samples. Pathol 2016; 48: 60-71.

49. Prentice CR. Acquired coagulation disorders. Clin Haematol 1985; 14: 413-442.

50. Gosselin R, Dager W, Roberts A et al. Effect of telavancin (Vibativ) on routine coagulation test results. Am J Clin Pathol 2011; 136: 848-854.

51. Pengo V, Tripodi A, Reber G et al. Update of the guidelines for lupus anticoagulant detection. Subcommittee on Lupus Anticoagulant/Antiphospholipid Antibody of the Scientific and Standardisation Committee of the International Society on Thrombosis and Haemostasis. J Thromb Haemost 2009; 7: 1737-1740.

52. Lessire S, Douxfils J, Baudar et al. Is Thrombin Time useful for the assessment of dabigatran concentrations? An in vitro and ex vivo study. Thrombos Res 2015; 136: 693-696.

53. Barrett YC, Wang Z, Frost C, Shenker A. Clinical laboratory measurement of direct factor $\mathrm{Xa}$ inhibitors: anti-Xa assay is preferable to prothrombin time assay. Thromb Haemost 2010; 104 1263-1271.

54. Gosselin RC, Francart SJ, Hawes EM et al. Heparin-Calibrated Chromogenic Anti-Xa Activity Measurements in Patients Receiving Rivaroxaban: Can This Test Be Used to Quantify Drug Level? Ann Pharmacother 2015; 49: 777-783.
55. Spannagl M, Bichler J, Birg A et al. Development of a chromogenic substrate assay for the determination of hirudin in plasma. Blood Coagul Fibrinolysis 1991; 2: 121-127.

56. Douxfils J, Mullier F, Loosen C et al. Assessment of the impact of rivaroxaban on coagulation assays: laboratory recommendations for the monitoring of rivaroxaban and review of the literature. Thrombos Res 2012; 130: 956-966.

57. Schmitz EM, Boonen K, van den Heuvel DJ et al Determination of dabigatran, rivaroxaban and apixaban by ultra-performance liquid chromatography - tandem mass spectrometry (UPLCMS/MS) and coagulation assays for therapy monitoring of novel direct oral anticoagulants. J Thromb Haemost 2014; 12: 1636-1646.

58. Douxfils J, Mani H, Minet V et al. Non-VKA Oral Anticoagulants: Accurate Measurement of Plasma Drug Concentrations. Biomed Res Int 2014; 2014: 345138.

59. Gous T, Couchman L, Patel JP et al. Measurement of the direct oral anticoagulants apixaban, dabigatran, edoxaban, and rivaroxaban in human plasma using turbulent flow liquid chromatography with high-resolution mass spectrometry. Therap Drug Monit 2014; 36: 597-605. 